\title{
Fishing in the city for food-a paradigmatic case of sustainability in urban blue space
}

\author{
Sofie Joosse $\mathbb{i D}^{1 凶}$, Lara Hensle (iD) ${ }^{1}$, Wiebren J. Boonstra (D) $^{2}$, Charlotte Ponzelar (iD) and Jens Olsson (iD ${ }^{3}$
}

This article presents fishing in the city for food (FCF) as a trenchant example of urban ecology, and the ways in which urban dwellers use, interact with, and depend on urban blue spaces. Our literature review demonstrates how FCF is studied in a diverse body of scientific publications that rarely draw on each other. As such, FCF and its relevance for sustainable and just planning of urban blue space remain relatively unknown. Using the literature review, a survey of FCF in European capitals, and examples from FCF in Stockholm, we demonstrate how attention to FCF raises pertinent and interrelated questions about access to water, food and recreation; human health; animal welfare and aquatic urban biodiversity.

npj Urban Sustainability (2021)1:41; https://doi.org/10.1038/s42949-021-00043-9

\section{INTRODUCTION}

By $2050,88 \%$ of the global population will be living in cities ${ }^{1}$. The global urban population is already drawing intensively on ecosystems worldwide for various basic needs such as food, water, and clean air, and other public benefits such as recreation opportunities. The projected increase in urbanisation will only increase these demands, and, in so doing, impact the sustainability of ecologies worldwide ${ }^{2}$.

Urbanisation has evoked a concern for making cities more resilient and sustainable (see, e.g., sustainable development goal 11) and a rediscovery of the function and importance of ecosystems situated in urban landscapes ${ }^{3-5}$. A growing number of publications across various scientific disciplines have now studied how ecologies in cities are important for meeting the needs of urban populations ${ }^{6}$.

However, most attention in the transdisciplinary field of urban sustainable development is devoted to the study of urban green space (for an important exception see Beatley ${ }^{7,8}$ ). Less visible (both literally and metaphorically) are the species and socioecological interactions found in-or related to-city waters, or blue space. Much remains unknown about the ecological health and sustainability of urban blue space, and the ways in which urban dwellers use, interact with and depend on its ecology and biology. Hence, it is still unclear how urban blue space contributes to and is dependent on, sustainable urban development and wellbeing ${ }^{9}$. In this paper, we focus on urban blue space and propose fishing in the city for food (FCF) as a trenchant example of the relation between urban ecologies and urban sustainability and justice.

Many city waters have historically provided their inhabitants with an important source of protein in the form of fish (see e.g. Ericson Wolke ${ }^{10}$ ). But during the second half of the 20th-century commercial fisheries in and close to cities often disappeared due to dwindling fish stocks caused by pollution, overfishing, and habitat destruction, but also because more powerful economic sectors acquired control over urban waterfronts and waterways $^{11,12}$. Alongside the marginalisation of commercial fisheries, the significance of urban waters for food provisioning seems to have also ceased. In this article we nuance the idea that urban blue space is insignificant for urban food provisioning by putting the spotlight on fishing in the city for food.

We focus here specifically on fishing in the city, and as such exclude semi-urban fishing, fishing communities outside the city that are influenced by urbanisation processes, and fishers living in the city but fishing outside ${ }^{13}$. A focus on the city itself is warranted because this limited geographical area and environment accommodate a range of different functions, and different socioeconomic and cultural groups, and as such can be considered a microcosm of society. FCF then is an everyday practice through which urban dwellers use and relate to (blue spaces in) their cities.

FCF addresses a number of general questions and matters of concern regarding environmental sustainability and justice that are at stake in the use and governance of urban blue space. To elucidate these questions and concerns, we first present a review of the literature on FCF. From this general level, we then move to an intermediate level to illustrate the significance of FCF through an overview of the occurrence of FCF in European capitals, and lastly, we present our own observations of fishers in Stockholm city as an example of FCF. We use these three sets of results together to discuss what insights and questions a study of FCF can generate for understanding the significance of urban blue space, in the light of urban justice and sustainability.

\section{RESULTS}

\section{Literature review}

To establish what has been published about FCF, we searched in Web of Science and Google Scholar for the following keywords and phrases: urban fishing; urban angling; city fishing; fishing for food in the city; subsistence fishing; urban fishers /fishermen; city angling; city fisher; city fishing toxin; hazardous substance city/ urban fishing; fishing/angling in the city). We then performed a forward and backward snowballing of the references in the papers that we found. This exercise resulted in a non-exhaustive list of 285 broadly relevant papers from academic fields such as fisheries (management), economics, history, aquatic science, risk studies, development studies, sustainability science, environmental impact assessment, urban studies, anthropology, toxicology, marine

${ }^{1}$ Department of Urban and Rural Development, Swedish University of Agricultural Sciences, Uppsala, Sweden. ${ }^{2}$ Department of Earth Sciences, Uppsala University, Uppsala, Sweden. ${ }^{3}$ Institute for Coastal Research, Department of Aquatic Resources, Swedish University of Agricultural Sciences, Öregrund, Sweden. ${ }^{凶}$ email: Sofie.Joosse@slu.se 
policy, sociology, leisure research, consumption studies, natural resource management, education, ecology, health, planning, rural development, and human geography. We also included grey literature, such as reports, conference proceedings, student theses, etc.

From the collection of articles that we generated through this search, we selected only those that discussed (directly or indirectly) "fishing for food" and "fishing in the city". This means that articles about fishing for food but not in the city, or about fishing in the city but not discussing fishing for food, or about urban fish but not about fishing, or about fishers living in urban areas but fishing elsewhere, were omitted. This selection resulted in 135 articles about fishing in the city for food. We analysed the articles in this final set of publications based on topic, country of study and publication year to discern strands, trends, and geographical spread in the literature. For detailed information see Supplementary Table 1.

The literature on FCF is geographically uneven. Of the total of 135 articles, 104 are about the USA. The USA literature offers valuable insights into FCF, but insights from the USA context (a high-income country with large income differences and a longstanding nationwide urban fishing programme) cannot unreflectively be used for understanding FCF globally or in other places. Other high-income countries that are included in our review with more than one entry are Canada ( 2 articles), the Czech Republic (2 articles) and Germany (5 articles). Further, 15 articles focus on urban fishing in upper-middle-income countries: Brazil (5 articles), South Africa (6 articles), Malaysia (1 article), Mexico (1 article), and China ( 2 articles). In the first four of these countries, FCF is approached more as a livelihood security and/or justice issue, whereas in China it is discussed in relation to public health.

While they feature in the first collection of 285 articles, low- and lower-income countries were generally absent when we narrowed our focus to fishing in the city for food. Most articles from low- and lower-income countries focus on fishers that live in the city but go fishing elsewhere outside the city, often with boats (e.g. Kadfak ${ }^{14}$ ), or semi-urban fishing communities ${ }^{15,16}$, or urban fish farming (e.g. Abayomi ${ }^{17}$ ). As such, these publications did not qualify to be included in our selection of articles about fishing in the city for food. Nevertheless, they discuss related and relevant issues and highlight the diversity that can be described by the term "urban fishing". We suspect that the lack of articles about FCF from lowand lower-income countries does not reflect the importance or prevalence of fishing in the city for food in those countries, but rather that FCF is under-researched in these contexts, or not researched as a topic separate from fishing in general, or that this research cannot be found through common search engines for academic research.

In our review of the final set of 135 articles on FCF, we distinguish two main strands (each consisting of more than 30 articles) and two minor strands (both consisting of fewer than 20 articles), which characterise the literature on FCF. The first main strand is called urban fisheries management. This strand discusses broadly characteristics of fishing in the city, and most articles are specifically about urban fisheries management. In this strand, 51 of the 57 papers are from the USA, where urban fishing programmes started as a nationwide initiative in 1969, initially to provide fishing opportunities for disadvantaged neighbourhoods specifically ${ }^{18}$. Over time this focus developed into the more general goals of providing fishing opportunities for the growing urban population; recruiting new fishers to increase licence sales that pay for fisheries management; and promoting environmental stewardship and helping urban residents to reconnect with nature ${ }^{19}$. Many of the articles in this strand are policy- and management-oriented, originating from urban fishing symposia for professionals (see, e.g., the collection in Eades et al. ${ }^{20}$ ). Reminiscent in scope and approach to the USA research, studies have been performed in Germany ${ }^{21}$ and the Czech Republic ${ }^{22}$.
These articles share a focus on management issues such as fish stocking for urban fishing lakes ${ }^{23}$, or the educational and recreational value of urban fishing programmes ${ }^{24}$. They regularly discuss the recruitment of new anglers to urban fishing programmes $^{25}$ and, to this end, present the characteristics, attitudes and preferences of fishers. The articles understand fishing practices through categorising anglers (using indicators, such as age, income, gender, or ethnicity), thereby paying less attention to fishing as a social practice shared by groups, with informal norms and routines. While most of the urban fisheries that are analysed in this strand allow harvesting of fish, the articles seldom discuss the use of fish as food. Consequently, there is little attention in this strand to the health risks that come with eating potentially contaminated fish.

The second main strand focuses on the public health effects of the consumption of city fish and contains information about: the contaminants (organic pollutants such as PCBs and dioxins, and inorganic pollutants such as mercury and other heavy metals) and pathogens (such as bacteria and parasites) that fish species in urban waters can contain; the fishers' knowledge about the health risks of eating city fish; and the effectiveness of the fish consumption advisories. From the total of 48 articles in this strand, 43 articles present research about the USA, two are from China, one is from South Africa, and one is from Germany. In contrast to the first strand that focuses on regulated spaces for urban fishing, this literature often studies non-regulated urban fishing ${ }^{26,27}$. There are some exceptions, and these articles call for more attention to be given to issues of health and contamination in urban fishing programmes ${ }^{28-31}$. In common with the first strand, many articles categorise anglers according to age, income, gender, ethnicity, etc., to better understand their risk perception and fish consumption practices ${ }^{32,33}$. A majority of articles from the USA in this second strand argue that some ethnic groups in US cities eat more contaminated fish than others, and investigate why this is $\mathrm{so}^{28,34}$. An important recommendation coming from this literature is that consumption advisories need to better adjust to ethnic groups ${ }^{35,36}$.

A third, rather small, strand of 23 papers centres around environmental justice in urban fisheries and highlights how structural inequalities are manifest in unequal access to safe food and good fishing grounds. One group of USA scholars criticises the focus, characteristic of strand two, on improving consumption advisories for ethnic groups, which they argue is based on a too limited understanding of the problem. They point out that for many fishers and their families the fish caught may be an economically and culturally important part of their diet. Therefore, however well-meant and -designed the advisories may be, avoiding fish consumption is hardly an option for these fish$\mathrm{ers}^{37-39}$. The scholars in this third strand stress the importance of protecting and cleaning urban fishing waters from pollution, as a minority and/or low-income groups will continue to depend on the resource in the foreseeable future ${ }^{38,39}$. Moreover, scholars like Shilling ${ }^{40}$ and Corburn ${ }^{41-43}$ argue that the ethnic groups affected by contaminated fish should be invited to co-design interventions better suited to their everyday reality than those devised by expert-driven consumption advisories. Also part of this third strand is a group of articles that describe how subsistence fishers in Brazil ${ }^{44}$, South Africa ${ }^{45-47}$, and 19th century USA ${ }^{48}$ have been, or are being, displaced and marginalised because of urbanisation and gentrification. The articles discuss how many cities are being designed for an urban middle class and elite ${ }^{46}$, in which fishing for food is seen as undesirable or unimportant, and as such made invisible 47 , marginalised or criminalised through rules and regulations 45,48 , or simply neglected in public policy and city planning ${ }^{49}$.

The fourth and last strand is also small (7 articles), but includes rather recent studies, and concerns urban foraging, i.e., harvesting or gathering raw biological resources (fungi, plants, parts of plants, 


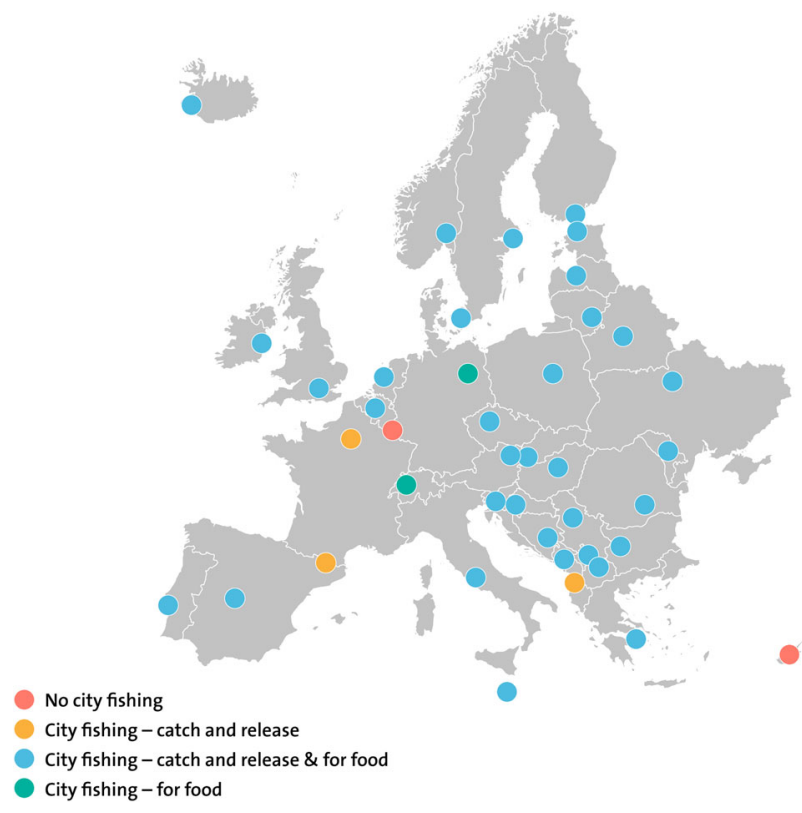

Fig. 1 City fishing in European capitals, design Azote.

invertebrate and vertebrate animals, and fish) within urban and peri-urban settings primarily for direct consumption, decoration, crafts, barter, or small-scale sale ${ }^{50}$. This literature only mentions fishing as a practice of urban foraging and focuses strongly on urban green spaces and the collection and eating of plants. Some studies highlight urban foraging as a strategy for urban poor people (including children) to diversify their diets with foraged foods ${ }^{51,52}$. Other articles in this strand, again mostly from the USA, take up a broad range of issues, including how foraging can bring a deeper connection between people and their city and inner-city nature, discuss urban foraging as a political act of reclaiming the city ${ }^{53}$, and point to alternative economies that urban foraging facilitates, by e.g., sharing instead of selling and buying food ${ }^{54}$. This literature posits that urban foraging is performed all over the world by a variety of people, but is nevertheless neglected as a topic of study ${ }^{50}$. The studies discuss how it is often made illegal $^{50,55}$, though some cities (e.g., Seattle) increasingly allow and open up for foraging ${ }^{53}$, or make shorelines accessible and fishing possible 56,57 .

The four strands in the literature on FCF, as we identify them here, overlap, leave gaps, and create tensions. Each has its specific focus and generates an understanding of FCF from that particular perspective. These understandings do not always resonate with each other. The first strand is based on the assumption that FCF is beneficial for people (health benefits through recreation) and the environment (because fisheries are managed, generating revenues from fishing licences in the urban fishing programmes, and promoting environmental stewardship). The second strand, in contrast, highlights the health risks associated with FCF and eating the catch. Where this strand primarily discusses improved consumption advisories as a solution to stop people from eating polluted fish, the third strand stresses that broader environmental injustices need to be considered to mitigate health risks. The third strand, moreover, argues that expert advice alone will not be helpful, but that affected groups and communities need to be included in both the formulation of the problem and the design of public health interventions. The third and fourth strands overlap to a considerable extent as they both highlight how FCF makes structural inequalities visible, and discuss, for example the criminalisation and marginalisation of FCF; the importance of FCF for livelihood security; and FCF as one way in which urban residents reclaim the city for everyday non-commercial activities as alternatives to neoliberalism.

Despite the overlaps and tensions highlighted here, the different literatures seldom draw on each other, and they rarely resonate beyond the various disciplinary fields on which they draw (such as fisheries management, toxicology/risk communication, anthropology/political ecology). However, the management, public health, environmental justice, and livelihood security aspects of FCF are closely interrelated, and therefore need to be approached through interdisciplinarity to create sustainable urban development. In the discussion section we return to the literature review and discuss which themes, stemming from the gaps and tensions, but also the blind spots in the literature, we believe, are worth more attention. But, before we do that, we will first move from literature to practice and establish the phenomenon, by describing the spread of FCF in Europe.

\section{European quick scan on fishing in the city for food}

We performed a quick scan of the occurrence of FCF in European capitals. The quick scan was limited to Europe because of time constraints. Moreover, the limited literature on this topic in Europe (in contrast to the USA, where there is much more) justifies this focus. We operationalised Europe as the countries of the European Union, plus the countries that are geographically part of Europe (see map in Fig. 1). We excluded transcontinental countries such as Russia and Turkey and very small countries such as Liechtenstein and Monaco.

We performed short semi-structured interviews by telephone, with staff at urban fishing equipment shops in European capitals. These staff members are suitable key informants for the quick scan because they know the fishing and fishers in their city, and likely have contact with urban fishers as customers in their shops. However, urban fishing equipment shops in several European cities target foremost sports fishers, sell sports fishing gear and promote catch and release as 'the ethical way of fishing'. Therefore, urban fishers for food may come less often to these shops and the shop staff may thus underestimate FCF in their city. For this paper this potential underestimation was not a methodological problem: we aimed to demonstrate the spread of FCF, not the frequency. Even if our respondents from the fishing shops may have underestimated it, they still gave evidence of FCF in most European capitals.

We targeted fishing shops close to the city centre and urban waters, in order to access the most urbanised and populated areas, which we were interested in as they represent the most extreme case of mixing fishing and urban environment. When we could not get hold of shop owners close to the centre, we called shops further away, and if we could not reach the shop holders at all we widened our search and contacted sport fishing associations, fishing tour guides, fishing/water authorities, municipalities, and/or tourist offices, and Facebook fishing groups. The interviews were performed in English, Dutch, or German by ourselves, except for Rome and Prague where we made use of translators. In some cases, the shop owners - at their own request-answered by mail instead of by telephone.

The quick scan consisted of the following themes: (1) Do people fish in the city? Where? (2) Who fishes? (3) What fish do they target? (4) Do they eat their catch? (5) Who owns the water and how can you get access? Only the answers to questions 1, 2, and 4 were used for this paper (see Fig. 1 and, in more detail, Supplementary Table 2).

Of the 41 cities included in the quick scan, only Luxembourg and Nicosia reported having no urban fishers (red dots on the map in Fig. 1), as it is prohibited to fish in the river in Luxembourg, and in Nicosia, the river is dry for a large part of the year. Of the remaining 39 cities, urban fishers were reported to only practise catch and release (orange dots on the map in Fig. 1) in three cities. 


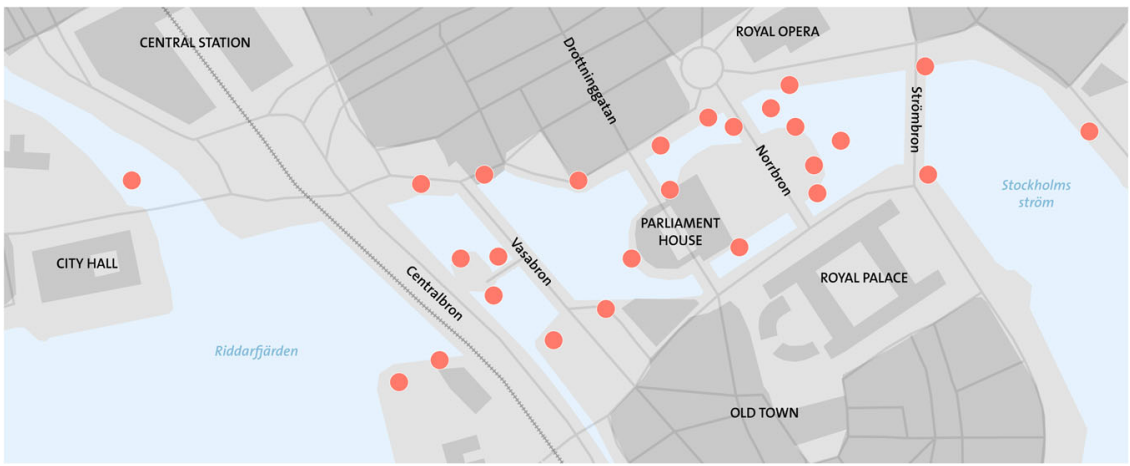

Fig. 2 Fishing spots in Stockholm inner city, design Azote, Based on data from OpenStreetMap, licensed under Open Data Commons Open Database License (ODbL).

In Tirana, our respondent stated that people choose to catch and release to preserve the fish stocks. Paris and Andorra la Vella allow urban fishing, but prohibit eating (and selling) fish caught in the city. In Paris, city fish have been deemed unfit for human consumption since 2010 because of the health risks that come with eating contaminated fish. We do not know the motivation behind the prohibition in Andorra la Vella. The Paris and Andorra la Vella regulations are in marked contrast to regulations in Germany and Switzerland (green dots on the map in Fig. 1), where you can only fish if you intend to eat the fish, as catch and release is considered inhumane and therefore prohibited. Interesting differences between European countries in animal welfare legislation thus exist, which impact the opportunities for FCF.

While FCF was reported in all remaining 36 cities (blue and green dots on the map in Fig. 1), there are differences. First, some capitals are directly adjacent to the open sea, while city fishers in other capitals only have access to urban lakes or canals, and in some cities, FCF takes place in the centre of the cities, while in others it is in the outskirts. These different locations may affect the rules and regulations and practices of FCF. Second, cities also differ in how common our respondents say it is to eat fish caught in the city. We have divided the answers into three categories. Respondents say that: (1) nearly all fishers eat the fish (Athens, Berlin, Bern, Helsinki, Kiev, Riga, Skopje, and Tallinn); (2) some fishers eat and some practise catch and release (Amsterdam, Belgrade, Bratislava, Copenhagen, Lisbon, Ljubljana, London, Madrid, Minsk, Oslo, Prague, Reykjavik, Rome, Sarajevo, Sofia, Stockholm, Valletta, Vienna, Vilnius, and Warsaw); and (3) few fishers eat the fish (Brussels, Bucharest, Budapest, Dublin, Pristina, Podgorica, and Zagreb). For Chisinau, we have too little information to say whether many or few fishers are eating their catch. The results from this quick scan will be discussed in more detail in section 3, where they are used to formulate questions for future consideration.

It is important to bear in mind that the quick scan is explorative. It confirms that while there are differences (in ecology, regulations, practices, and perspectives), FCF is widespread across European capitals. In the next section, we focus on the example of Stockholm to illustrate how FCF may look.

\section{The example of FCF in Stockholm, Sweden}

Between autumn 2018 and spring 2020 we regularly visited the city centre of Stockholm to find and meet with city fishers in order to gain a better understanding of their fishing practices and motivations. We performed 37 field visits spread over the year, over the days of the week and the times of the day. During these field visits, we counted 383 people fishing, and we interviewed 106 fishers, who gave us informed consent.

The field visits (by the first and second author) ranged from two hours to a whole day. Only five times out of the 37 visits did we not find any fisher at all. This had to do with either very cold weather, or-as we later found out-that we did not look in the right places for the fishers. Indeed, when we had established better contact with the city fishers, they told us that the fish in city waters are not always found at the same location and that the fishers follow the fish. To give an example of this fisher mobility, during summer 2019 we were very surprised to one day find no fisher at all in the city centre. When we contacted our respondents by phone they told us they had instead relocated to the fringes of the city centre as it was now the season to catch Baltic herring. On some occasions, we also visited fishers outside the city centre, when they had notified us they would fish elsewhere. Most of our fieldwork, however, was in Stockholm inner city, in a very busy tourist area, close to the Parliament and City Hall (see Fig. 2).

The following is a short account of fishing in Stockholm, to give an idea of what FCF in a capital city can look like (see also Boonstra et al. ${ }^{11}$ ).

The city fishers of Stockholm are a diverse group, mostly men and some women, and range from families on a day out, to tourists, refugees, IT professionals fishing during their lunch break, seasonal labour migrants, pensioners, and groups of kids and teenagers. This diversity is exemplified in the account below, of a field visit in Stockholm.

On a Friday morning in early April, we walked our round in the city centre and soon met a Swedish-speaking fly fisher fishing for sea trout (Salmo trutta). He was dressed in a typical sport fishers outfit with a multi-pocket vest and had a camera taped to his shoulder. He told us he lives just outside of Stockholm and works in IT in the city centre. While we were talking he was filming with a camera, as he was planning to put the movie on YouTube. He told us he never eats the fish he catches but always practises catch and release. We continued our round and met four fishers just behind the Parliament, fishing together from the jetty. They told us they were pensioners and originally from the Middle East and had been living in Stockholm for many years now. They were fishing for anything sizable that would take the bait (several worms on a hook, dug up in the forest), but these days it was foremost bream (Abramis brama). We were surprised at the amount of fish they reeled in-six during the half an hour we were there-and they told us they would catch around 40 per day, a whole blue IKEA bag full. While this was a good spot now, they would soon move to a fishing spot some $4 \mathrm{~km}$ away, as there would be other fish to catch then.

The Stockholm fishers' fishing practices vary a lot, according to their different purposes, gear, and ideas about ethics, but like many of the other fishers we talked with, these fishers are very knowledgeable about the ecology of the city waters. Stockholm has a variety of micro-environments differing in salinity, vegetation cover and type, water transparency and water currents, which attracts and favours different species of fish. Many fishers are well aware of the seasonal movements, habits, and habitats of the fish 
they target. To exemplify: several of them commented on specific fish stocks decreasing as a result of, in their view, a reduction in the stocking of fish, increased bird and seal predation, and increased outtake of fish by commercial fisheries. They also observed, and told us about, an increase in parasites in specific fish species.

A majority of the fishers (73 fishers out of 106 interviewed) reported eating their catch always or sometimes; others would practise catch and release. We were surprised about how different ethical and good fishing practices were discussed: some deemed fishing for food unsustainable and unethical as it might decrease the fish stocks; others found the catch and release unethical as it was causing fish unnecessary suffering. With so many different fishing practices, cultures and perspectives in one location, there are also tensions, prejudices and stigmatisation, especially when it comes to fishing for food. The fishers told us there would sometimes be heated discussions about releasing or eating the fish caught.

Another issue that fishers have different opinions about is the health risk associated with eating city fish. While some would definitely not eat the fish out of health considerations, others would minimise their intake, while yet others sometimes deemed Stockholm city fish of better quality than fish sold in supermarkets. Some fishers told us they targeted specifically those fish that were, or reminded them of, the fish they needed for their traditional dishes but that were hard to obtain in Swedish shops. We also met fishers and groups of fishers who caught more than they could eat. They would prepare the surplus fish for storage, by e.g., pickling, frying or freezing. Fishers also told us they would share or trade with friends and family, neighbours and in their networks. For a few, Stockholm city fishing is important for their livelihood security.

The fishers had a variety of reasons for fishing, among which enjoyment and accessibility were very important. Many enjoyed the hunt and the catch, being outside and meeting other fishers; some saw fishing as meditative and as an activity for stress relief. Several fishers emphasised the accessibility of urban fishing. For some, accessibility was about capital: without owning a car or boat they could still get to fine fishing waters. Others-working right in the city centre-described urban fishing as accessible because it was close to work, and they could fish during their lunch break. Several fishers without employment explained that fishing as an activity gave meaning and structure to their everyday life, a way to get out of the house and come home with some food. Fishing in Stockholm is typically a social activity. While some fishers preferred to be alone, we often saw people fishing in groups, or engaging in small talk with other fishers. They told us about informal "rules" for fishing in the city, having to do, for example, with helping each other out, and what fishing spots to use. Some fishers enjoyed the interest from tourists who ask about Stockholm fish and fishing and attention from spectators who gather when a sizable fish is caught.

To summarise, fishing in Stockholm is a common and social activity practised by a broad range of people, in different ways, and for different reasons. As such, fishing in Stockholm raises a number of questions about the status and impact of the activity on the targeted fish stocks, human health, ethical treatment of animals, livelihood security and stigmatisation, and fishing as a social practice with (informal) rules and routines.

\section{DISCUSSION}

While we only have evidence from a limited number of countries, we believe that FCF is performed all over the world, by rich and poor, young and old, women and men, employed and unemployed, migrants and long-term residents (see also Paddeu ${ }^{54}$ ). People engage in FCF for a variety and combination of reasons, including recreational (enjoying the outdoors, and the sport of fishing, stress relief), social (fishing with others, giving fish to others), cultural (e.g., targeting fish important for a cultural dish), nutritional (e.g., complementing diets), economic (e.g., selling or trading), and gaining skills and understanding of their city's nature. Fishing in the city for food is criminalised in some countries, stigmatised in others, or plainly forgotten in urban planning and policy in yet other countries. While some urban dwellers fish in regulated spaces and purchase fishing licences, others fish in unregulated spaces, or fish illegally. There are public health concerns about eating fish from the city, and even in regulated spaces standardised tests of contaminants in the fish are lacking ${ }^{29}$.

Based on our study, we argue that FCF justifies continued and interdisciplinary attention from scientists and policymakers working for urban sustainable development, for three reasons. First, we deem the topic to be societally relevant because people depend differently on FCF, health risks are spread out unevenly, and FCF is in many contexts not considered in city planning and environmental monitoring. Second, our literature review highlights several gaps: many articles about FCF merely mention the phenomenon and do not investigate it further; research on FCF is often compartmentalised and different literatures seldom build on each other; and, we found few articles about FCF from lowermiddle and low-income countries even though FCF is expected to be both abundant and important there. Third, FCF displays processes and relations that otherwise are often more covert: it involves people who often remain unseen and unheard, and who are engaged in and using an urban ecology that is for the most part unknown.

FCF has the potential to function as a paradigmatic case of urban sustainability and environmental justice. Taking FCF as the entry point, studies can elucidate processes related to urban sustainability and justice processes or mechanisms that are less visible/pronounced elsewhere: (1) how people affect nature, e.g., how urban fishing, and broader urban activity and industry, impact the targeted fish stocks; (2) how nature affects people, e.g., through food and health, recreation; (3) how people-from sometimes very different cultural backgrounds-interrelate in competition as well as collaboration over access to, and use of, both safe and healthy land and water. As such, FCF invites research attention to a number of aspects (outlined below) that illustrate the interrelated challenges of establishing resilient natural environments in urban areas and ensuring just, sustainable and ethical use of these areas for a wide variety of groups.

First, as literature about the benefits and risks of FCF remain largely separate from each other, we identify the need to study these aspects together, and with the involvement of relevant groups/communities of fishers. Such studies could fruitfully be linked to the influence of FCF on urban aquatic ecology, which brings us to the next topic.

Second, there is limited knowledge about how FCF affects urban fish populations and urban aquatic ecosystems more broadly. There are a number of articles that discuss the effects of FCF on aquatic ecosystems, mostly featuring urban lakes. But from a perspective on environmental sustainability, more knowledge is needed about the impact of FCF on ecosystem resilience. For some cities, it might be necessary here to also consider the combined pressure that FCF and commercial fishing together place on fish populations ${ }^{58}$.

Third, our study suggests the importance of FCF for livelihood security: eating, trading, or selling the catch in informal networks or local markets. As such, FCF blurs the regular distinctions between subsistence, commercial, and recreational fishing (see also Cooke et al. $^{59}$ ). The contribution of FCF to urban livelihood security for different societal groups and in different contexts needs to be investigated and acknowledged. More research on this aspect is needed in lower-middle and low-income countries. Here especially, we expect FCF to be important for groups of 
urban dwellers, but most literature that we found on FCF published in academic journals focuses on high and uppermiddle-income countries.

Fourth, the FCF literature does not devote much attention to animal welfare and the ethics of FCF. Yet, our results indicate strong opposing perspectives on how to ethically handle and kill fish. In our quick scan, we found how different countries apply different animal welfare considerations to motivate regulations pertaining to killing fish (e.g., Berlin does not allow fishing if the intention is not to keep the fish, as catch and release is considered to cause the fish unnecessary suffering). And, in our Stockholm study, we noticed that the different groups of fishers and people passing by have contrasting ideas about ethics related to fishing. As killing is very visible in FCF-it happens on the streetdifferent moral perspectives are quickly articulated, such as in this example discussed in the popular press in Germany, where passers-by became upset when an urban fisher killed a fish ${ }^{60}$.

Fifth, our study documents the stigmatisation of specific sociocultural groups who fish for food. The literature discusses the directed criminalisation of FCF in various contexts, and our own studies showed how some respondents consider (certain forms of) FCF undesirable from e.g. the perspective of public health or sustainability. In the quick scan, some respondents distinguished specifically between fishers from their own country and fishers with other cultural backgrounds and nationalities, such as between English and Eastern European, or Italian and Roma. Also, the literature reports the stigmatisation of different cultural groups and their fishing practices. One publication, interestingly, proposes everyday urban fishing practices in Sydney as a useful lens to better understand conflicts between different cultural groups $^{61}$.

Finally, from our Stockholm study, we can confirm the wellrehearsed argument (see e.g., Hind ${ }^{62}$, Johannes ${ }^{63}$, Boonstra et al. $^{11}$ ) that people who frequently fish are often knowledgeable about the local environment and what lives and happens in the water. Some fishers document their catch and share the information on fish apps such as www.fishbrain.com, or with friends through social media. As fish in urban waters are typically less monitored, fishers' knowledge can be a viable complementary or alternative source of information for conventional scientific research on the status of aquatic biodiversity in cities.

By way of conclusion, we consider the relevance and implications of FCF for the planning and governance of just and sustainable cities. Attention for sustainable planning of urban green spaces, and the food and related values they produce, is increasing ${ }^{6}$, but our literature review demonstrates that food, values and practices connected to urban blue spaces are seldom considered in the urban planning literature (a notable exception is Beatley ${ }^{7,8}$ ).

When we use FCF as an entry into urban blue planning, the question of the right to the city becomes central. FCF reminds us to ask ourselves what a city is for and for whom. The literature review clarified that in several contexts fishers are driven out from the city, as public areas adjacent to water become commercialised, or restricted and closed. While this is sometimes the result of purposeful planning, and sometimes of unintended neglect, the results are the same, and often harm the urban poor.

Just and sustainable FCF poses a challenging task for planners, for which they will also need to consider how the knowledge and preferences of urban fishers can be relied upon to make policy and planning relevant, legitimate, and effective. From our experience with FCF in Stockholm, we know that some urban fishers are well-organised in associations and clubs, which could facilitate their involvement in the design and monitoring of urban policy and planning. There are also examples of how fishers organise themselves in reaction to pressures to their fishing $\operatorname{sites}^{47}$. But city fishers are a motley crowd with many different practices and interests, and a large proportion of these fishers are not formally organised or easily reached. On the contrary, some of the fishers might actively avoid engagement with formal organisations and authorities, due to language barriers, legal status or the purpose and the practices of their fisheries. Reaching this latter group and involving them in planning and policy is a challenge, but central to the task.

To consider FCF is to consider how the growth of cities worldwide ties together issues of livelihood security, environmental sustainability and social justice. Highlighting and understanding these issues in context is crucial for securing sustainable and just use of urban blue spaces.

\section{DATA AVAILABILITY}

The data that support the findings of this study are available on request from the corresponding author. The data are not publicly available due to privacy or ethical restrictions.

Received: 8 March 2021; Accepted: 19 November 2021; Published online: 20 December 2021

\section{REFERENCES}

1. United Nations, Department of Economic and Social Affairs, Population Division. World Urbanization Prospects: The 2018 Revision (ST/ESA/SER.A/420). https:// population.un.org/wup/Publications/Files/WUP2018-Report.pdf (2019).

2. McDonald, R. I., Beatley, T. \& Elmqvist, T. The green soul of the concrete jungle: the urban century, the urban psychological penalty, and the role of nature. Sustain. Earth 1, 1-13 (2018).

3. Wolch, J. R., Byrne, J. \& Newell, J. P. Urban green space, public health, and environmental justice: the challenge of making cities 'just green enough'. Landsc. Urban Plann. 125, 234-244 (2014).

4. Andersson, E., Tengö, M., McPhearson, T. \& Kremer, P. Cultural ecosystem services as a gateway for improving urban sustainability. Ecosyst. Serv. 12, 165-168 (2015).

5. Tzoulas, K. et al. Promoting ecosystem and human health in urban areas using Green Infrastructure: a literature review. Landsc. Urban Plann. 81, 167-178 (2007).

6. Andersson, E. et al. Reconnecting cities to the biosphere: stewardship of green infrastructure and urban ecosystem services. AMBIO 43, 445-453 (2014).

7. Beatley, T. Blue Urbanism: Exploring Connections Between Cities and Oceans (Island Press, Washington, DC, 2014).

8. Beatley, T. Blue Biophilic Cities: Nature and Resilience Along the Urban Coast (Springer, Switzerland, 2018).

9. Foley, R. \& Kistemann, T. Blue space geographies: enabling health in place. Health Place 35, 157-165 (2015).

10. Ericson Wolke, L. Stockholms Historia Under 750 år. (Svenska Historiska Media Förlag $A B, 2015)$.

11. Boonstra, W. J., Björkvik, E., Joosse, S., \& Hanh, T. T. H. From Anthrome to Refugium? A short history of small-scale fisheries in the Anthropocene. in I Encyclopedia of the World's Biomes. Reference Module in Earth Systems and Environmental Sciences (eds Goldstein, M. I. \& DellaSala, D. A.) (Elsevier Science, 2019).

12. Parikh, A. Urban commons to private property: gendered environments in Mumbai's fisher communities. Environ. Plann. D 39, 271-288 (2021).

13. Carlson, A. K., Boonstra, W. J., Joosse, S., Rubenstein, D. I. \& Levin, S. A. More than ponds amid skyscrapers: urban fisheries as multiscalar human-natural systems. Aquat. Ecosyst. Health Manag. (Forthcoming) (2022).

14. Kadfak, A. More than Just Fishing: The Formation of Livelihood Strategies in an Urban Fishing Community in Mangaluru, India. J. Dev. Stud. 56, 2030-2044 (2020).

15. Palanca-Tan, R. Social capital and vulnerability to extreme climate in a semi-urban fishing community in Laguna de Bay, Philippines. J. Environ. Sci. Manag. 23, 89-101 (2020).

16. Utete, B., Phiri, C. \& Fregene, T. B. Drivers and barriers to sustainable fisheries in two peri-urban impoundments in Zimbabwe. Water SA 45, 560-567 (2019).

17. Abayomi, E., Balogun, O. S., Omonona, B. \& Yusuf, S. An analysis of risk factors among urban fish famers in Kaduna. Kaduna State J. Agric. Vet. Sci 2, 21-35 (2013).

18. Pape, L. D., \& Eades, R. T. What's in a Name? Urban Versus Community Fisheries Programs. In Urban and Community Fisheries Programs: Development, Management, and Evaluation (eds Eades, R. T., Neal, J. W., Lang, T. J., Hunt, K. M. \& Pajak, P.) 67, 133-141 (American Fisheries Society Symposium, 2008).

19. Neal, J. W., \& Eades, R. T. Urban and Community Fisheries Programs: Development, Management, and Evaluation-A Summary. in Urban and Community Fisheries Programs: Development, Management, and Evaluation (eds Eades, R. T., Neal, J. W., Lang, T. J., Hunt, K. M. \& Pajak, P.) 67, 455-463 (American Fisheries Society Symposium, 2008). 
20. Eades, R. T., Neal, J. W., Lang, T. J., Hunt, K. M. \& Pajak, P. Urban and Community Fisheries Programs: Development, Management, and Evaluation. (American Fisheries Society Symposium, 2008).

21. Arlinghaus, R. \& Mehner, T. Characteristics of Anglers Living in The Metro-Politan Area of Berlin (Germany): Implications for Urban Fisheries Management and Research. in Regional Experiences for Global Solutions: The Proceedings of the 3rd World Recreational Fishing Conference, 21-24 May (eds Coleman, A. P. M.) 117-120 (Northern Territory, 2002).

22. Lyach, R. \& Čech, M. A new trend in Central European recreational fishing: More fishing visits but lower yield and catch. Fish. Res. 201, 131-137 (2018).

23. Lang, T. J., Neal, J. W., \& Hutt, C. P. Stocking Frequency and Fishing Quality in an Urban Fishing Program in Arkansas. In Urban and Community Fisheries Programs: Development, Management, and Evaluation (eds. Eades, R. T., Neal, J. W., Lang, T. J., Hunt, K. M. \& Pajak, P.) 67, 379-390 (American Fisheries Society Symposium, 2008).

24. Cohen, M. K., Lee, N., Nichol, M., \& Guthrie, C. I fish NY: Outreach and Education in New York City and on Long Island. In Urban and Community Fisheries Programs: Development, Management, and Evaluation (eds Eades, R. T., Neal, J. W., Lang, T. J., Hunt, K. M. \& Pajak, P.) 67, 305-330 (American Fisheries Society Symposium, 2008).

25. Balsman, D. M. \& Shoup, D. E. Opportunities for Urban Fishing: Developing Urban Fishing Programs to Recruit and Retain Urban Anglers. In Urban and Community Fisheries Programs: Development, Management, and Evaluation (eds Eades, R. T., Neal, J. W., Lang, T. J., Hunt, K. M. \& Pajak, P.) 67, 31-40 (American Fisheries Society Symposium, 2008).

26. Beehler, G. P., McGuinness, B. M. \& Vena, J. E. Characterizing Latino anglers' environmental risk perceptions, sport fish consumption, and advisory awareness. Med. Anthropol. Q. 17, 99-116 (2003).

27. Burger, J. Fish consumption advisories: knowledge, compliance and why people fish in an urban estuary. J. Risk Res. 7, 463-479 (2004).

28. Knuth, B. A., McOliver, C., Silbergeld, E. K., Connelly, N. A., \& Faulds, A. Contaminant and pathogen considerations in urban fisheries: balancing the fishing experience with the need to protect human health. in Urban and Community Fisheries Programs: Development, Management, and Evaluation (eds Eades, R. T., Neal, J. W., Lang, T. J., Hunt, K. M. \& Pajak, P.) 67, 143-164 (American Fisheries Society Symposium, 2008).

29. Lucas, D. \& Polidoro, B. Urban recreational fisheries: implications for public health in metro-Phoenix. Chemosphere 225, 451-459 (2019).

30. Lurig, L., \& Pflugh, K. K. Development and evolution of the New Jersey Department of Environmental Protection's Urban Fishing Program. In Urban and Community Fisheries Programs: Development, Management, and Evaluation (eds Eades, R. T., Neal, J. W., Lang, T. J., Hunt, K. M. \& Pajak, P.) 67, 271-279 (American Fisheries Society Symposium, 2008).

31. McOliver, C. C., Craczyk, T. K., \& Silbergeld, E. K. Assessing the Risks of Exposure to Cryptosporidium from Recreational Water Activities in Baltimore, Maryland. in Urban and Community Fisheries Programs: Development, Management, and Evaluation (eds Eades, R. T., Neal, J. W., Lang, T. J., Hunt,

K. M. \& Pajak, P.) 67, 455-463 (American Fisheries Society Symposium, 2008).

32. Bingham, M. F. et al. Integrating revealed and stated preference data to improve the estimation of baseline risk fish ingestion. Tech. Work. Paper 2014-3, 1-35 (2014).

33. Lauber, T. B., Connelly, N. A., Niederdeppe, J. \& Knuth, B. A. Urban anglers in the Great Lakes region: Fish consumption patterns, influences, and responses to advisory messages. Sci. Total Environ. 590-591, 495-501 (2017).

34. Burger, J. Consumption patterns and why people fish. Environ. Res. 90, 125-135 (2002).

35. McDermott, M. H. Communicating a complex message to the population most at risk: an outreach strategy for fish consumption advisories. Appl. Environ. Educ. Commun. 2, 23-37 (2003)

36. Fisher, C. L., Westphal, L. M., \& Longoni, M. Fish consumption risk perception among anglers in an industrial urban area. In Proc. 2009 Northeastern Recreation Research Symposium (eds Watts, C. E. Jr. \& Fisher, C. L.) 48-56 (U.S. Department of Agriculture, Forest Service, Northern Research Station, 2010).

37. Christian-Smith, J. et al. A Twenty-First Century U.S. Water Policy (Oxford University Press, 2012).

38. Shand, E., Johnson, M., Duma, J., \& Matsumoto-Hervol, M. Beneath the Surface Urban Fishing and Environmental Justice. https://minds.wisconsin.edu/handle/ 1793/73417 (2013)

39. West, P. C., Fly, J. M., Larkin, F., \& Marans, R. W. Chapter 8: Minority Anglers and Toxic Fish Consumption: Evidence from a State-Wide Survey of Michigan. in Race And The Incidence of Environmental Hazards: A Time for Discourse (eds Bryant, B. \& Mohai, P.) 100-113 (Routledge, 1992).

40. Shilling, F. M. Fishing for justice or just fishing. Ecol. Law Curr. 36, 205 (2009).
41. Corburn, J. Street Science: the Fusing of Local and Professional Knowledge in Environmental Policy. (Massachusetts Institute of Technology, 2002).

42. Corburn, J. Combining community-based research and local knowledge to confront asthma and subsistence-fishing hazards in Greenpoint/Williamsburg, Brooklyn, New York. Environ. Health Perspect. 110, 241-248 (2002).

43. Corburn, J. \& Gottlieb, R. Street Science: Community Knowledge and Environmental Health Justice. (MIT Press, 2005).

44. Perry, K.-K. Y. "If We Didn't Have Water": black women's struggle for urban land rights in Brazil. Environ. Justice 2, 9-14 (2009).

45. Kalina, M. R., Mbereko, A., Maharaj, B. \& Botes, A. Subsistence marine fishing in a neoliberal city: a political ecology analysis of securitization and exclusion in Durban, South Africa. J. Polit. Ecol. 26, 363-380 (2019).

46. Maharaj, B. Contesting displacement and the struggle for survival: the case of subsistence fisher folk in Durban. S. Afr. Loc. Econ. 32, 744-762 (2017).

47. Dray, A. The politics of the privatisation of public space: the subsistence fishers of Durban, KwaZulu-Natal. (University of KwaZulu-Natal, Durban, 2009).

48. Thrush, C. (2006). City of the Changers. Pac. Hist. Rev. 75, 89-117 (2005).

49. Pedrosa, B. M. J., Lira, L. \& Santiago Maia, A. L. Urban fishers from the coastal zone of the State of Pernambuco, Brazil. Bol. Inst. Pesca 39, 93-106 (2013).

50. Shackleton, C. M., Hurley, P. T., Dahlberg, A. C., Emery, M. R. \& Nagendra, H. Urban foraging: a ubiquitous human practice overlooked by urban planners, policy, and research. Sustainability 9, 1884 (2017).

51. Garekae, H. \& Shackleton, C. M. Foraging wild food in urban spaces: the contribution of wild foods to urban dietary diversity in South Africa. Sustainability 12 678 (2020).

52. Lee, S. E. Child Self Provisioning in a Marginal Urban Environment. (University of Georgia, Athens, 2007).

53. Poe, M. R., McLain, R. J., Emery, M. \& Hurley, P. T. Urban forest justice and the rights to wild foods, medicines, and materials in the city. Hum. Ecol. 41, 409-422 (2014).

54. Paddeu, F. Waste weeds, and wild food. A critical geography of urban food collecting. EchoGéo 47, Article 47 (2019).

55. Sachdeva, S., Emery, M. R. \& Hurley, P. T. Depiction of wild food foraging practices in the media: impact of the great recession. Soc. Nat. Resour. 31, 977-993 (2018).

56. Limburg, K. E., Hattala, K. A., Kahnle, A. W., \& Waldman, J. R. Fisheries of the Hudson River Estuary. In The Hudson River Estuary (eds Levinton, J. S., Levinton, J. S. \& Waldman, J. R.) 189-204 (Cambridge University Press, 2006).

57. West, P. C. Invitation to poison? Detroit minorities and toxic fish consumption from the Detroit river. In Race And The Incidence Of Environmental Hazards: A Time For Discourse (eds Bryant, B. \& Mohai, P.) 96-99 (Routledge, 1992).

58. McKenzie, C. J. A. \& Cox, S. P. Building legitimacy of the recreational fishing sector in mixed commercial-recreational fisheries. Ocean Coast. Manag. 75, 11-19 (2013).

59. Cooke, S. J. et al. The nexus of fun and nutrition: recreational fishing is also about food. Fish Fish. 19, 201-224 (2018).

60. Leppert \& Stillbauer. Tod Eines Riesigen Fischs am Main bei Frankfurt Sorgt für Aufregung. https://www.fr.de/frankfurt/eines-riesigen-fischs-main-frankfurtsorgtaufregung13792019.html (2020).

61. Goodall, H., Wearing, S., Byrne, D., \& Cadzow, A. Fishing the Georges River: cultural diversity and urban environments. In Everyday Multiculturalism (eds Wise, A \& Velayutham, S.) 177-196 (Palgrave Macmillan, UK, 2009).

62. Hind, E. J. A review of the past, the present, and the future of fishers' knowledge research: a challenge to established fisheries science. ICES J. Mar. Sci. 72, 341-358 (2015).

63. Johannes, R. E., Freeman, M. M. R. \& Hamilton, R. J. Ignore fishers' knowledge and miss the boat. Fish Fish. 1, 257-271 (2000).

\section{ACKNOWLEDGEMENTS}

This research has been supported by FORMAS (grant Nos. 2015-01053 and 201901901).

\section{AUTHOR CONTRIBUTIONS}

Conceptualisation: S.J. and L.H. Investigation: S.J., L.H., and C.P. Analysis: S.J, L.H., and C.P. Interpretation: S.J., L.H., W.B., C.P., and J.O. Writing-original draft preparation: S.J. Writing-review and editing: S.J., L.H., W.B., C.P., and J.O. All authors have read and agreed to the submitted version of the paper.

\section{FUNDING}

Open access funding provided by Swedish University of Agricultural Sciences. 


\section{COMPETING INTERESTS}

The authors declare no competing interests.

\section{ADDITIONAL INFORMATION}

Supplementary information The online version contains supplementary material available at https://doi.org/10.1038/s42949-021-00043-9.

Correspondence and requests for materials should be addressed to Sofie Joosse.

Reprints and permission information is available at http://www.nature.com/ reprints

Publisher's note Springer Nature remains neutral with regard to jurisdictional claims in published maps and institutional affiliations.
Open Access This article is licensed under a Creative Commons Attribution 4.0 International License, which permits use, sharing, adaptation, distribution and reproduction in any medium or format, as long as you give appropriate credit to the original author(s) and the source, provide a link to the Creative Commons license, and indicate if changes were made. The images or other third party material in this article are included in the article's Creative Commons license, unless indicated otherwise in a credit line to the material. If material is not included in the article's Creative Commons license and your intended use is not permitted by statutory regulation or exceeds the permitted use, you will need to obtain permission directly from the copyright holder. To view a copy of this license, visit http://creativecommons. org/licenses/by/4.0/.

(c) The Author(s) 2021 